Gerontologia 1969;15:378

\title{
Varia
}

\section{Die Universität Uppsala}

hat einen Lehrstuhl für Gerontologie (Geriatrie) aufgestellt und Professor L.A. Carlson vom Karolinska Institut auf diesen berufen.

For recent research on

'The Role of Inorganic Substances in the Nutrition of Aged Persons' a price of Sfr. 15000.- shall be awarded in September 1970 by the «Central Union of Milk Producers of Switzerland» as «Members of the International Dairy Association».

Applicants are asked to send their papers published since 1964, in 3 copies (if possible in English, German or French) and their Curriculum vitae, not later than May 1st 1970 to the chairman of the jury: Prof. Dr. F. Verzár, Institute of experimental Gerontology, Nonnenweg 7 , 4000 Basel, (Switzerland).

European Section of the International Association of Gerontology

The European Section of the International Association of Gerontology shall hold its third, triennial Symposium 5th-9th April 1970 in Leeds, England. For registration apply to the Secretariat, Department of Medicine, General Infirmary, Leeds LSI 3 EX, England. Final date for submission of abstract

$\mathrm{s}$ is 1 . December 1969.

14th Ciba Foundation Lecture on Aging

The 14th Ciba Foundation Lecture on Ageing will be delivered by Prof. L. Hayflick of Stanford University, California, during the Meeting of the European Section of the Intern. Ass. of Gerontology in Leeds 5.-9. April 1970.

Skin Aging and Cancer Research Center

The University of Pavia (Italia) has created a "Skin Aging and Cancer Research Center". Director is Prof. Dr. F. Serri (Policlinico S. Matteo, Pavia). The University will administer the funds and grants of the institution. 